\title{
The Utility of Information on Selective Exposure of Pornographic Information through Internet on Student of Islamic Boarding School in Tangerang City
}

\author{
Rio Pambudi Dalimunte ${ }^{1}$, Inge Hutagalung ${ }^{2}$ \\ \{riopambudi89@gmail.com ${ }^{1}$, inge_hutagalung@yahoo.com / inge_hutagalung@mercubuana.ac.id ${ }^{2}$ \} \\ Universitas Mercu Buana, Jakarta, Indonesia ${ }^{1,2}$
}

\begin{abstract}
This study wants to see the role of the utility of information on pornography among students in XYZ modern Islamic boarding school in Tangerang. This study uses a constructivist paradigm as a basis for thinking. The research method is a case study design using a qualitative approach. Data collection techniques using is in-depth interview methods. This type of interview allows researchers and informants to have a dialogue, and questions that have been prepared previously can be modified according to the informant's response. The results of the study showed that pornographic information could help students to have more understanding about reproductive health, and strengthen attitudes to reject pornographic information. Pornographic information is only useful to the increase knowledge related to sex education and not to be an indication of how to carry out sexual activities. Furthermore, the student stated information on important pornography, and was close to everyday life and they were very curious about pornography. However, all these things are only limited to understanding and knowledge about sex, not for sexual behavior. This is due to the upbringing of the Islamic boarding school which requires the student to submit and obey the rules of the Islamic boarding school..
\end{abstract}

Keywords: Pornography, Utility of Information, Regulation of Islamic Boarding School.

\section{Introduction}

Based on the 2015 Google Trend survey it is known that Indonesia is the fifth largest country in the world accessing pornography with the keyword "sex" on internet search engines. As for the city where the word 'sex' is accessed, Jakarta occupies the 4th position under Delhi, Hanoi and Mumbai. What is of concern, when examined more deeply, it turns out that the biggest accessors of pornographic material are students (Hutagalung, 2018a).

From the results of a survey conducted by the Ministry of Health, a picture shows that teenagers in Indonesia have indeed been exposed to pornographic information. Namely, from 1,411 respondents who are students in the South Jakarta area and Pandeglang Regency, Banten, 97 percent of students are known to have access to pornographic information (jakarta.tribunnews.com, March 2019). Meanwhile, the 2018 Ministry of Women's Empowerment and Child Protection (KPPPA) survey showed surprising results. As many as 97 percent of 1,600 children in grades 3 to 6 in elementary school have been exposed to pornography. This survey was conducted in eight provinces throughout Indonesia (Jawapos.com, March 2018) 
To overcome the problem of pornography web, until November 2018 as many as 106,466 sites containing pornographic content were blocked by the Ministry of Communication and Information. The total numbers of pornographic sites that have been blocked are 883,348 sites since 2010 (Press Release No. 322 /HM/KOMINFO/12/2018).

Pornography has a serious negative impact because it can damage the brain and psychological individual. Not only the impact on individuals who are pornographers, pornography addiction also causes adverse impacts on the environment such as increasing cases of violence and sexual harassment as well as the destruction of order and norms in society (Seminar on the Impact of Pornography on Reproductive Health, 2019). The Indonesian Child Protection Commission (KPAI) recorded the number of complaints on child cases during 2018 of 4,885 cases. The pornography and cybercrime cases were in third position with the total of 679 cases. Children exposed to pornography through social media usually lead to sexual abuse and rape. Boys dominate as perpetrators compared to girls (Indonesian Child Protection Commission, 2018).

The question that arises in addressing this condition is why teens often access pornographic information?

Research Rachmaniar and colleagues (Rachmaniar, 2018) and Mariyati (Mariyati \& Aini, 2018) describe that adolescence is a time of very crisis. At this time the foundation of reproductive health for a lifetime. This period is a period where sexuality appears in the form of physical and psychological changes. The psychological changes known as puberty appear in the form of psychological things such as feelings, emotions and awareness about sexuality and interest in the opposite sex. At this level, adolescents try to find sexual information to meet the desires and needs of the opposite sex sexuality.

On the other hand, Anisah's research (Anisah, 2016), Hutagalung (Hutagalung, 2017), and Mahsiani (Mahsiani, 2018) explained that adolescents often look for pornography information because teenagers have difficulty finding sources of information on sexuality. To ask parents about sexuality is very unlikely because it is considered taboo, asking teachers about sex information would be embarrassing. As a result, adolescents look for sexuality information on pornographic information through mass media, especially on social media.

Research related to the utility of information among adolescents has often been done by experts. Several studies have been conducted by Beyens (Beyens, 2014), Tserkovnikova (Tserkovnikova, 2016), Alexandraki (Alexandraki, 2018), Hutagalung (Hutagalung, 2018a) related to the utility of pornographic information on the information selection process among adolescents. Based on previous research searches, researchers see a gap to conduct research related to the utility of pornographic information on the process of information selection among modern boarding students. Namely, whether the search for pornography information via the internet still has uses for teenagers in Islamic boarding schools related to increased knowledge about sex. This is interesting to study considering the pattern of fostering of Islamic boarding schools that are centered on the rules of boarding schools that are very strict, and boarding schools have the view that the issue of sex is sacred and should not be arbitrary access to information about sex.

As the focus of research selected teenagers from XYZ modern Islamic boarding schools in the city of Tangerang. The argument for choosing Tangerang is because Tangerang is the city at the border of the capital city of Jakarta that based on the 2015 Google Trend survey is the fourth city in the world to access pornographic information on the internet. 


\section{Literature Review}

\subsection{Selective Exposure Theory}

Cognitive dissonance theory is a theory that places individuals as active actors in the communication process. Namely, that when dissonance arises then people tend to avoid information that is contrary to beliefs or attitudes, and choose information that is in accordance with beliefs and attitudes. In other words, people will make the selection and rejection of information known as selective exposure.

There are 4 theories that explain selective exposure, namely reinforcement theory, cognitive dissonance theory, uses and gratification theory, mood management theory. Each theory provides a different explanation of why selective exposure occurs. This study underlies the analysis of selective exposure from the perspective of cognitive dissonance theory. The reason for the selection is that the theory of cognitive dissonance is the first theory that describes the phenomenon of selective exposure.

Previously, experts only realized that people have the power to reject and elect information related to their opinions or beliefs, without realizing that this condition is a phenomenon of selective exposure. This period is referred to as de facto selective exposure (Freedman, 1965; Zillmann \& Bryant, 1985).

Literature search shows that the cause of selective exposure based on the perspective of cognitive dissonance theory involves three aspects, namely psychological, message and social aspects. Meanwhile, the theory of strengthening predisposition only involves one aspect, namely social, consisting of group norms. The theory of usability and gratification only involves one aspect, namely psychological, including the emphasis on the use of information based on meeting one's needs. Mood management theory also only involves one aspect, namely psychological, including mood.

Selective exposure (in the perspective of cognitive dissonance theory) was introduced by Leon Festinger as a person's ability to choose between information that supports and rejects conflicting information. Festinger (Festinger, 1957) asserted that selective exposure is an attempt to reduce or eliminate dissonance. When inconsistencies or dissonance occur, people will look for information based on their beliefs.

Over time, tracing the results of selective exposure research based on cognitive dissonance theory by experts shows that people do not always induce selective exposure based on belief. People may choose or consume information that is not appropriate (dissonant) as long as information has a usefulness (perceived utility of information). In this case the choice is explained as a result of the characteristics of the message itself. So the information chosen does not have to be information that is in accordance with beliefs, but also conflicting information as long as the information can fulfill the individual's usefulness of information ( $S$ Knobloch-Westerwick, Carpentier, Blumhoff, \& Nickel, 2005; Silvia Knobloch-Westerwick, 2003).

Meanwhile, David (David, 2005) and Hutagalung (Hutagalung, 2018a) explained that people's choice of media or information is not only determined by individual factors (individual interests and needs), but also is determined by social structure, in the form of social norms (including appropriateness, politeness, trust and others) in a society. Individual choice and social structure must be seen as a 'duality' that influences one another. Individuals are formed by structure (social norms) and at the same time individuals can also change and shape the structures that exist in that society. 
The discovery of the phenomenon of selective exposure cannot be separated from the long journey of mass media impact research. Mass communication research until around the 1950s had a tendency to pay more attention to the impact of the media on the audience, namely how the media influenced the audience and the impact of the media on their behavior. In the use of media and information, individuals are often assumed to be passive in receiving information rather than being actively seeking, selecting and filtering existing information. Over time, the research of Lazarsfeld (1944) and Hovland (1949) made theorists aware that audiences have resistance (rejection) of information. At that time, although they were aware that the audience carried out a selection process for information, the term selective exposure was not yet known. On the other hand, very little attention is paid to experts on the phenomenon of the choice and rejection of media and information carried out by individuals. Only after Festinger's explanation (1957) through the theory of cognitive dissonance, terminology related to the selection and rejection of media and information carried out by individuals is known as selective exposure (Baran, 2000; Zillmann \& Bryant, 1985).

\subsection{Utility Of Information Theory}

Canon states that an individual's behavior in choosing and avoiding information is not merely caused by whether the information creates consonance or dissonance, but rather is triggered by the utility of the information for themselves. Canon is the expert who first emphasized the importance of utility/advantages as a basis for individual to choose and avoid information (Silvia Knobloch-Westerwick, 2003).

In 1973, Atkin developed Canon's ideas regarding the utility of information in the information selection process (S Knobloch-Westerwick et al., 2005; Silvia KnoblochWesterwick, 2003). Atkin emphasized that selective exposure is carried out by individuals to fulfill the usefulness of information.

In the process in fulfilling the utility of information, individuals not only conduct information selection that is useful or suitable with their belief, but also will conduct information selection that is detrimental to or contrary to belief. The information chosen does not have to be information in accordance with their belief, but also conflicting information provided that the information can fulfill the individual's use of information, namely the use of instructions, strengthening attitudes and how to do things.

The results of Festinger (1964), Cannon (1964), Freedman and Sears (1965), Freedman (1965a), Katz (1968), Cotton (1985), Frey (1986) also proved that people in selective exposure not only pay attention and choose information that is in accordance with beliefs, but will also pay attention and choose information that has utility (utility of information), even though the information is conflicting (dissonant) (Hutagalung, 2018a).

Researchers such as Levy and Windahl (S Knobloch-Westerwick et al., 2005; Silvia Knobloch-Westerwick, 2003) developed the Atkin idea. According to them, selective exposure is done to fulfill an individual's use of information. Selection is not determined by whether the information is appropriate or not in accordance with someone's dissonance, but rather because of the use of information. And that utility will increase is determined by three dimensions, namely magnitude/the perceived magnitude of challenges, the possibility of information will occur (loneliness / the perceived likelihood of their materialization), and immediacy in time (immediacy/i.e., proximity in time of their materialization). The larger the scale of information, the more likely the information is, the closer to information, the more useful information will be for an individual. 


\section{Methodology}

This study uses the constructivist paradigm as the basis of the framework. The research method is a case study design using a qualitative approach. The technique of collecting data uses the method of in-depth interviews. This method was chosen because pornography is a sensitive and personal issue.

Furthermore, data analysis in this study uses technical inductive analysis, namely (1) after collecting data in the form of raw data from research results, such as interviews, documentation, field notes and so on, the data is reduced, through the editing process, grouping and summarizing data, compiling codes and notes about various things found, so that the themes, groups and data patterns are obtained. (2) Presentation of data, i.e. organizing data or interweaving groups of data together with other data so that all analyzed data is really involved in a single research process. (3) Withdrawal and conclusion testing: the conclusion takes place procedurally. The final conclusion in the form of scientific proportions regarding the phenomenon or reality under study, through consulting empirical findings by looking at the concepts or theories put forward earlier.

As a research informant selected students from modern Islamic boarding schools in Tangerang. In the context of this study, students are representative of adolescents. There are seven informants, that consist of four male gender and three female gender.Tangerang is selected because Tangerang is the city at the border of the capital city of Jakarta that based on the 2015 Google Trend survey is the fourth city in the world to access pornographic information on the internet.

\section{Results and Finding}

\subsection{Results}

The informants in this study were consisting of seven people. In the presentation of the results of this study, the five informants used initial names in accordance with the agreement, namely, four male gender (AH, SP, BP and IG) and three female gender (SP, DP, PW).

\subsubsection{Understanding about pornography}

In the context of this study, all informants stated that pornography is information related to sexual exploitation and obscenity. Following is the statement from one of the informants:

"I understand pornography as information related to sexual problems that are exposed vulgarly. Pornographic information is also often interpreted as obscenity. In my opinion, the interpretation of one person's obscenity with others will be different. For example, seeing a breast image for someone might be considered obscene, but someone else is considered usual image, and so on" (Male informant: BP).

\subsubsection{The source of pornography information}

In the context of this study, the informants obtained pornographic information from the internet, mobile phones, and from conversations with fellow friends. Following is the statement from one of the informants: 
"Information on pornography is usually obtained from the internet, or the information can be sent from friends through mobile phones. The information can take the form of pictures, films or caricatures. Sometimes, pornographic information can also be obtained through conversation with colleagues. In conversation, pornographic information is usually become a joke material" (Male informant: $A H)$.

\subsubsection{The curiosity about pornography}

In the context of this study, all male informants (AH, SP, BP, IG) expressed their interest in pornography, while the three female informants (HP, DP, PW) did not have the desire to know about pornography. Here is the statement from one of the male informants:

"I really want to know pornographic information. The reason is, because pornography can give me a little knowledge about reproductive health and physical and psychological changes that I experience today" (Male informant: SP).

Meanwhile, statements from female informants, one of which is:

"I do not want to know pornographic information, because that information is prohibited by religion and the laws of the Indonesian government. I also don't want to know information that contains elements of obscenity" (Female informant: DP).

\subsubsection{Advantages of pornographic information}

In the context of this study, informants were divided in addressing the advantages of pornographic information. Female informants (HP, DP, PW) stated that pornographic information had no advantages at all, while male informants stated that pornographic information had advantages to increase knowledge related to sexuality. The following is the statement of one of the informants who represents the revelation of the use of pornographic information and the usefulness of pornographic information:

"Information on pornography has no benefit at all. And is misleading information because it encourages teens to engage in sexual activity and promiscuity. In other side, free sex is prohibited by religion" (Female informant: $P W)$.

"The information on pornography is very useful. A lot of information related to physical development and on the functions including reproductive organs that I do not understand, such as how sex hormones in men are continuously needed by the testicles. How sex hormones can help push the inner part. In addition to the lack of understanding related to sexuality, information related to change is very difficult to find. Through information on pornography, some knowledge about sexuality can be obtained, even though pornographic information is conveyed vulgarly" (Male informant: IG).

\subsubsection{The proximity of pornographic information in everyday life}

In the context of this study, the informants stated that pornography is very close to everyday life. Pornographic information is everywhere. From wide screen films, television, comics, novels, newspapers, tabloids, magazines, VCDs/DVDs, cellphones, and internet sites, it shows that pornography is easy to find.

The informants also agreed to state that pornography can not only be displayed through images, but also through forms of writing, sound and gestures. Following is the statement from one of the informants: 
"Information on pornography is very close to everyday life. Pornography is everywhere. From wide screen films, television, comics, novels, newspapers, tabloids, magazines, VCDs /DVDs, cellphones, and internet sites presenting pornographic and direct shows that are easy to find, both in big and small cities, even to rural though. Pornography has mushroomed in people's lives, and the funny thing is that information is not only consumed by teenagers but also by the adults" (Male informant: SP).

\subsubsection{Attitude reinforcement towards pornography}

In the argument of this research, the informants discussed about the benefits obtained from pornographic information, it was realized that pornography encouraged adolescents to behave freely. Having sex before marriage can arise social problems such as pregnancy, abortion, sexually transmitted infections, HIV/AIDS, cervical cancer and others. Pornography encourages adolescents to apply sex permissively. Here is the statement from one of the informants:

"Pornography can be applied as an alternative source of information about sex and reproductive health. This is actually understandable considering the high curiosity from the adolescents, because teenagers are very curious about the changes and turmoil that is happening to them, especially those concerning sexuality. On the other hand, many parents are less able to provide an understanding of sexual behavior to children correctly. As a result, many teenagers are seeking knowledge of sexuality through pornographic information. However, I am aware that pornographic is a mislead information. Understanding the pornography message content actually strengthens my attitude to stay away from pornographic information" (Male informant: BP).

\subsubsection{The role of Islamic boarding school in reinforcing attitudes towards pornography}

In the context of this research, the informants agreed to state that whatever benefits obtained from pornographic information, it was realized that pornography encouraged adolescents to behave freely. Pornography encourages adolescents to apply permissively to sex. On the other hand, the rules of Islamic boarding schools further strengthen the attitude of the informants to reject pornography. Some statement from one of the informants:

"I realized that I could get a lot of sexuality information through pornographic information. I also realized that pornography had a negative impact on our generation, such as the existence of permissiveness regarding sexual behavior. However, I feel very fortunate to be able to study in the Islamic boarding schools, because the rules on Islamic boarding schools that would not allow the pornography is getting strictly prohibited while strengthening my attitude to oppose pornography" ( Male informant: SP).

\subsubsection{Obedience to the rules of pornographic boarding school}

At the hearing of this study, the informants agreed to their statement about the rules of Islamic boarding school related to pornography. The issues that are forbidden in the Islamic boarding school regulations they will obey. Following is the statement from one of the informants:

"Although I can get a lot of sexuality information through pornographic information, however the Islamic boarding school regulations prohibit students from searching, downloading or collecting things related to pornography ... then I will comply with these 
regulations. I did this as one of my forms of obedience to the boarding school institution where I studied. On the other hand, I am also aware that violations of all the rules of the boarding school will be penalized" (Male informant: $I G$ ).

\subsection{Discussion}

From the results of the study note that the informants understood pornography. The informants' understanding is in accordance with the meaning of the word Porne which means brothel and Graphos which means writing or drawing. The term porne itself then gradually develops meaning into something related to sex, especially the notion of shameful sex (obscene sex) or sex with violence (violent sex). Thus, pornography can refer to images or writing that are related to sex. In the Big Indonesian Dictionary, pornography is interpreted as an erotic depiction of behavior with paintings or drawings to arouse lust (Supartiningsih, 2004).

Regarding the source of pornography, the informants agreed to state that social media is the main source for accessing pornographic information, in addition to conversations with peer-groups. Today with extraordinary developments in the field of information and communication technology technology that is so sophisticated, has made people not only live in the era of 'communication revolution', but also wading through what is called the era of communication abundance or cornucopias of communication.

The abundance of communication in this life has an impact on the continuous explosion of information brought by the media to one's personal life space. This information seems to flow without time through various types of media. One of the information that flows is pornography. Ranging from feature films, television, comics, novels, newspapers, tabloids, magazines, VCDs / DVDs, cellphones, and internet sites present pornography shows that are directly or indirectly easy to find, both in large and small cities, even to the countryside though.

Furthermore, the results of research related to curiosity about pornography show that there are two opinions. All male informants expressed their curiosity about pornography. This is in accordance with the study of Gunarsa (Gunarsa, 2004) which states that adolescence is the age at which a person is searching for and forming his identity. At this time the foundation of reproductive health for a lifetime. This period is a period where sexuality appears in the form of physical and psychological changes.

If male informants have a curiosity about pornography, then it is different from female informants. Female informants have no curiosity about pornography. According to researchers, this happens because pornography is a form of exploitation of women (especially women's bodies). Women become objects and victims of pornography. Because pornography is made by and for men, and makes women as mere objects.

Meanwhile related to the benefits of pornographic information, male informants stated pornography was useful, and vice versa to female informants. According to the researchers, the findings of this study also reinforce the idea of Atkin (1973) as outlined in the theory of utility of information. Namely, that one's motivation in choosing and avoiding information is not caused by whether the information causes consonance or dissonance, but rather is triggered by the utility of information for someone. The utility of information can only be felt when a person has an orientation goal and an adjustment goal that will be achieved through the acquisition of information, both negative and positive information (threats or opportunities), because each information is believed to have benefits. Namely, that information can be used to meet one's needs for guidance (how to judge something), 
reinforcement (reconfirmation of an attitude) and performance (how to do something). Because the selection and rejection of an information is based on the benefits, then in the process of fulfilling the need for individual information not only do the selection of information that is beneficial or in accordance with beliefs, but also will select information that is detrimental or contrary to belief.

In the case of pornography, teenagers actually need knowledge about sex, considering that sex is also related to the psychological development of adolescents. Through information about sex, adolescents can learn to take sexual decisions in an adult, guided and get an explanation of changes in the function of sexual organs as stages that must be passed in human life. In other words, knowledge about sex has benefits for adolescents to better understand what sex really is, and helps adolescents to go through any psychological developments related to the problem of sex itself. The utility of information perceived by adolescents to information about sex is what makes adolescents often choose information about pornography, although this information may be contrary to the beliefs held.

In the context of this study, the informants stated that pornography was very close to daily life. Pornographic information is everywhere. Changes in the approach of mass communication related to technological and informatics developments have resulted in an explosion of information that continues to flow into personal life. In the context of pornography, the change in communication approach from "one-for-many" to "many-for-one" and "many-for-many" communication models greatly accelerates the spread of information about pornography.

Furthermore, from the perspective of the public interest the existence of mass media in the community has a normative purpose as a steward of the interests of the community. Mass media has a close relationship with society precisely because mass media has an inevitable social function. The mass media is part of the community that has a role to serve the public in the delivery of information or news. But in reality many media do not carry out their social role because the goals of media organizations are more likely to be oriented towards pursuing business profits alone.

On the other hand, group support also plays a role in the process of selecting and rejecting pornographic information. The results showed that although pornographic information was felt by some informants to have the benefit of better understanding sexuality, informants stated that they would be subject to the rules of Islamic boarding schools. This can be understood because Islamic boarding schools are study groups for informants. As part of the study group, the informants will have normative beliefs based on group rules. In this case the rules are boarding schools. The strength of the influence of the environment/group on beliefs is very much determined by how closely and the individual's need to continue to establish communication with the group/existing social environment. The tighter and more necessary the stronger the influence of the environment/group on beliefs, and vice versa.

\section{Conclusion}

This research is based on the starting point that the utility of information plays a role in the process of selecting and rejecting information.

By taking the case of pornography, this study seeks to draw conclusions whether the utility of information has a role in selective exposure. Pornography is taken as a research case based on the argument that pornography is one of the social problems in Indonesia with an 
iceberg phenomenon that requires serious attention. The reason for selecting adolescents as research informants is because adolescents are the largest population targeted for pornography.

In the case of pornography, teenagers actually need knowledge about sex, considering that sex is also related to the psychological development of adolescents. Through information about sex, adolescents can learn to take sexual decisions in an adult, guided and get an explanation of changes in the function of sexual organs as stages that must be passed in human life. In other words, knowledge about sex has benefits for adolescents to better understand what sex really is, and helps adolescents to go through any psychological developments related to the problem of sex itself. The use of information perceived by adolescents to information about sex is what makes adolescents often choose information about pornography, even though the information may conflict with beliefs owned.

Another factor that has a significant role in selective exposure is group support. In the case of pornography, group support influences the choice and rejection of information about pornography. Group support is an individual effort to achieve balance with the social environment. Because deviations from the group usually will often lead to sanctions, both social/moral to legal sanctions. In short, the interactions that occur in groups, both interpersonal and group, can influence beliefs. Beliefs are values that are believed and embedded in themselves, due to the communication relationships that exist between individuals and groups can change according to the subjective norms of the group.

People are instinctively attracted to things that are taboo, like pornography. In the context of adolescents, the need for information about pornography is not only due to interest in taboo, but also because of the encouragement and demands of biological and psychological development. This makes teenagers often try to find information about sex through internet to increase their self-knowledge.

\section{References}

[1]. Alexandraki, K. (2018). Internet Pornography Viewing Preference As A Risk Factor For Adolescent Internet Addiction: The Moderating Role Of Classroom Personality Factors. Journal Behavioral Addictions, 7(2).

[2]. Anisah, N. (2016). Efek Tayangan Pornografi di Internet Pada Perilaku Remaja di Desa Suka Maju Kecamatan Tenggarong Seberang. Efek Tayangan Pornografi Di Internet Pada Perilaku Remaja Di Desa Suka Maju Kecamatan Tenggarong Seberang, 4(1).

[3]. Baran, S. (2000). Mass Communication.

[4]. Beyens, I. (2014). Early Adolescent Boys' Exposure to Internet Pornography: Relationships to Pubertal Timing, Sensation Seeking, and Academic Performance. Journal Early Adolescence, $35(8)$.

[5]. David, J. (2005). Television and Theories of Selective Exposure: Review and Directions for Future Research.

[6]. Festinger, L. (1957). A theory of cognitive dissonance. Scientific American. https://doi.org/10.1037/10318-001

[7]. Freedman, J. L. (1965). Confidence, utility, and selective exposure: a partial replication. Journal of Personality and Social Psychology, 2(5), 778-780. https://doi.org/10.1037/h0022670

[8]. Gunarsa, S. (2004). Psikologi Perkembangan Anak dan Remaja.

[9]. Hutagalung, I. (2017). The Utility of Information in Selective Exposure of Pornography Among Teenagers in Indonesia. International Journal of Social Relevance \& Concern, 5(5).

[10]. Hutagalung, I. (2018a). The Influence of Belief, Utility of Information, and Group Support on Selective Exposure to Pornography among Teenagers in Jakarta, Indonesia. International Journal of Engineering \& Tewchnology, 7(2.29), 557-563.

[11]. Knobloch-Westerwick, S. (2003). Effects of Salience Dimensions of Informational Utility on 
Selective Exposure to Online News. Journalism and Mass Communication Quarterly, 80(1).

[12]. Knobloch-Westerwick, S., Carpentier, F. D., Blumhoff, A., \& Nickel, N. (2005). Selective exposure effects for positive and negative news: Testing the robustness of the informational utility model. Journalism \& Mass Communication Quarterly, 82(1), 181-195. https://doi.org/10.1177/107769900508200112

[13]. Mahsiani, L. (2018). Is Parental Communication or Internet use that makes Pornography in Teenagers? Journal Child Development Studies, 3(1).

[14]. Mariyati, \& Aini, K. (2018). Studi Kasus: Dampak Tayangan Pornografi Terhadap Perubahan Psikososial Remaja. Ilmu Dan Teknologi Kesehatan, 9(2).

[15]. Rachmaniar, P. P. (2018). Perilaku Penggunaan Smartphone Dan Akses Pornografi Di Kalangan Remaja Perempuan,. Jurnal Komunikasi Global, 7(1).

[16]. Supartiningsih. (2004). Melacak Akar Masalah Pornografi dan Pornoaksi serta Implikasinya terhadap Nilai-nilai Sosial (Kajian Filsafat Nilai). Filsafat.

[17]. Tserkovnikova, N. (2016). Psychological Aspects of Internet Addiction of Teenagers. Journal Environmental \& Science Education, 11(6).

[18]. Zillmann, D., \& Bryant, J. (1985). Selective exposure to communication. In Cognitive dissonance in selective exposure (pp. 11-33) 